\title{
ПОНЯТТЯ ГРИ В СТРУКТУРІ ГУМАНІТАРНОГО ЗНАННЯ
}

\begin{abstract}
М.О. Чулошнікова
Незважаючи на поважний вік існування, людство не покидає такого «несерйозного» заняття як гра. Саме гра дозволяє Людині поєднати реальне та ілюзорне, наслідуване та індивідуальне, щире виявлення почуттів та акторську маску, справжню інтонацію та штамп. Це і є, як відзначає академік С. Аверінцев, «невідчепною ідеєю нашого століття». Цілком закономірно, що феномен гри досліджують сьогодні різноманітні галузі знання: філософія, психологія, соціологія, герменевтика, педагогіка, естетика, мистецтвознавство, культурологія, лінгвістика, логіка, математика. В попередніх статтях (див. [11], [12]) ми грунтовніше зупинялись на аналізі феномену гри в царині філософії і соціології, акцентуючи увагу на ролі гри в житті соціуму, на її структурі та складових (чинниках), особливостях взаємодії ігрових сторін-суб'єкта і об'єкта та інш. В цій статті ми робимо спробу прослідкувати, яким чином змінюється кут зору на феномен гри та аспекти його розглядання в історії розвитку людської культури та гуманітарного знання загалом.

Початок формування ігрових концепцій сягає ранніх часів становлення європейської культури. В епоху античності гра вперше постає як фундаментальна проблема буття. Широкого розповсюдження набули два протилежних (але при цьому ігрових!) пояснення Всесвіту: (1) розуміння життя як стихійної нерозумної гри космічних сил; (2) розуміння життя як сценічної гри, що грунтовно продумана вищим розумом.

Найбільш глибоку античну концепцію взаємодії ігрового і космічного створив Платон, який усвідомив буття крізь призму загальнодержавної гри та вперше надав грі широкого універсального змісту. Зміст ідеї Платона - в плані витлумачення сенсу життя людини - полягає в тому, щоб «жити граючи» в «прекрасніші ігри» (маються на увазі пісні, танці, битви з ворогами та жертвопринесення).
\end{abstract}

Актуальні проблеми духовності

(Відп. ред.: Я.В. Шрамко)

Кривий Ріг (2005), 273-279 
Аристотель сформулював тезу про неможливість «розчинити» життя в грі, тому що вважав гру такою, що «... існує для задоволення всупереч діяльності будь-якого гатунку, яка пов'язана з працею та напруженням» $[1$, c.630]. Внаслідок цього він стверджував, що ігри слід вводити, обираючи для них слушний час, надаючи їх в якості ліків, - «..бо рух під час гри являє собою заспокоєння душі та завдяки задоволенню - відпочинок» $[1$, с.630]. Ігри, на його думку, є тільки «вступом» для наступних занять, і тому навіть в якості терапевтичного засобу треба обирати тільки ті ігри, що «відтворюють майбутню діяльність» [1, с.625]. Проте, твердження Аристотеля, що гра є тільки задоволенням, а навчання, наприклад, пов'язано також з прикростями, не можна, на наш погляд, вважати ознакою невизнання за грою навчальної функції. Скоріш за все, вищезазначене можна розуміти як застереження Людині не «загратися» в процесі життя, полишивши поза увагою серйозні екзистенційні проблеми, що надалі породило вкрай протилежні трактування семантики гри.

Пізніше виникають схожі ідеї Цицерона щодо необхідності розмежування «серйозного» та «ігрового», та Квінтіліана-про розуміння гри тільки як особливого прийому навчання (див. [2]). Зауважимо, що сутність поняття «гра» була сферою уваги та філософського міркування Геракліта, який порівнював еон 3 «дитиною, що грає». В Новий час гра з'являється як форма «аргументу парі» Б. Паскаля, який порівнював екзистенціальний вибір людини з «грою в кістки». Німецька класична філософія висунула на перший план естетичний аспект гри (I. Кант, «Критика здібності міркування», Ф.Шіллер «Листи про естетичне виховання»). Г.В. Плеханов сформулював матеріалістичний погляд на гру, вказавши на її виникнення з праці (див. [3]).

Власне кажучи, певний час значна увага дослідників була зосереджена перш за все на усвідомленні ролі гри в житті людини та власне на самому гравцеві - на усвідомленні того, що саме мотивує його включеність в процес гри, заради чого він відволікається від утилітарної діяльності. У ХX ст. особливого значення набуває протилежний напрямок міркувань: на перший план виступає не суб'єкт, що грає, не місце і значення гри в процесі створення та розбудови культури, а саме феномен гри як такої. Гра «вивільняється» від людини (дегуманізується), однак наголос робиться на осмисленні їі онтологічного статусу, трансцендентної природи, що отримує оригінального осмислення в лінгвістичній філософії Л. Витгенштейна (див.: [6]).

Проте, не тільки онтологічному статусу, а також і розгляданню функції гри приділяється в філософії значна увага. Користуючись переважно символами для пояснення своїх основних категорій, філософія звертається до специфічних ігор, що дають можливість розтлумачити, зробити прийнятними навіть ті символи, що не мають власного денотату, тоб- 
то пояснити символ через інший символ. Як зазначає Л.Витгенштейн, розтлумачення такої складної комбінації стає можливим тільки через застосування «мовних ігор». В цьому перш за все і полягає особливість та специфічність мови філософії, тому в їі царині і застосовуються певні правила гри.

В галузі точних наук ігри прийнято розглядати як математичні моделі прийняття оптимальних рішень в умовах конфлікту, тобто в ситуації, коли при участі різних сторін, що наділені різними можливостями, необхідно здійснити вибір досяжних для сторін дій у відповідності з суб'єктивними інтересами. Створена так звана «теорія ігор», що охоплює як власне ігри (шахи, доміно), - так і різноманітні ситуації, що виникають в різних галузях активності людини. Ця теорія $є$ природнім розвитком теорії рішення задач в екстремальних умовах, в тому числі і умовах конфлікту. Таким чином, в межах математичної теорії ігор можна в принципі описувати змістовно досить різноманітні явища: питання спортивних змагань та економічної боротьби, військові, правові та класові конфлікти, боротьбу за існування тощо. Суттєвим є той факт, що теорія ігор моделює не тільки антагоністичні конфлікти, але й більш складні взаємини сторін носіїв різних інтересів. Важливу роль теорія ігор відіграє і в процесі розуміння інформації [8].

В дослідженнях багатьох психологів гра тлумачиться як форма діяльності в умовних ситуаціях, що спрямована на відтворення та засвоєння суспільного досвіду, фіксованого в соціально закріплених способах здійснення предметних дій, в предметах науки та культури. Зазначається, що в грі, як в особливому виді суспільної практики, що виник історично, відтворюються норми людського життя та діяльності, підпорядкування яким забезпечує пізнання та засвоєння предметної дійсності, інтелектуальний, емоційний та моральний розвиток особистості. Як відомо, у дітей дошкільного віку гра $є$ ведучим типом діяльності. Грою називають також певні форми життєдіяльності тварин. Відзначаючи деякі спільні риси поведінки людини та тварин під час ігор (незавершеність послідовності дій, вироблення нових комплексів рухів, змішання функціонально різних типів поведінки, невідповідність інтенсивностей окремих рухів та всієї послідовності в цілому тощо), дослідники приходять висновку, що попри надзвичайну складність та незавершеність розуміння функції гри «... фактори, що контролюють ігрову поведінку, далеко не є ясними, та без сумніву, безмежно складними» «... попри все, ігрова поведінка існує і ігнорувати її неможливо» $[4$, c.69]. Виходячи з розуміння гри як наперед визначеної даності (а не набутості), висловлюється припущення, що необхідність ігрової поведінки пов'язана з таким періодом в розвитку живої істоти, протягом якого вона повинна підготуватися до «дорослої» життєдіяльності. Значення гри полягає в тому, що в її процесі виробляються та 
удосконалюються різноманітні здібності, в тому числі здібність психічної регуляції власної діяльності. Отже, тренувальний характер і в межах психологічного аспекту розглядання феномену гри $\epsilon$ незаперечним. Відчуття задоволення, що викликано нею - основний її стимулятор. Така стимуляція в вищій мірі $є$ доцільною, тому що без гри не могли б сформуватися навички діяльності та поведінки, необхідні для існування живої істоти.

По суті, те, що людина не може не пройти стадію дитинства, пояснює і значення гри в її розвитку. Не випадково гра є, за словами Л.С. Виготського, «...не уявність і не удаваність для дитини...вона...є формуючою реальністю...» [5, с. 319]. За одностайним ствердженням психологів, гра - не тільки ведуча діяльність дитини, але й основа всього наступного розвитку, бо саме в грі вона початково набуває досвід для життя в суспільстві та розвиває всі ті фізичні та духовні потенції та здібності, що є для неї необхідними.

Фрейдисти вбачають в грі вираз глибинних інстинктів або потягів. Проте, ці тлумачення гри страждають біологізаторським підходом. В свою чергу, Е.Берн [2] пропонує дещо інший кут зору на гру, застосовуючи до її дослідження структурно-функціональний підхід. Він розбиває «Я» людини на три категорії: 1) стан «Я», схожий на образ батьків; 2) Стан «Я», автономно спрямований на об'ективну оцінку реальності, 3) Стан «Я», який все ще діє 3 моменту його фіксації в ранньому дитинстві і той, що є архаїчними пережитками. Неформально проявлення цих станів «Я» Берн називає «Батько, Дорослий та Дитина». Стосунки між цими складовими людського «Я» можна, на погляд Берна, тлумачити як ігрові, тому що вони відбуваються згідно зі схемою побудови гри: передбачають творення відповідного порядку в локальному просторі, спрямоване на досягнення певної мети не утилітарного(!) гатунку, означені відповідною символікою та термінологією, тощо.

В радянській психології теорію ігор, що походить від визнання її соціальної природи, розробляли Е.А. Аркін, Л.С. Виготський, А.Н. Леонт'єв (див. [3]). Пов'язуючи гру з орієнтовною діяльністю, Д.Б. Ельконін визначає її як діяльність, в якій складається та удосконалюється керівництво поведінкою [14]. Відмінними ознаками розгортання гри з точки зору психологів є ситуація, що швидко змінюється, та в якій опиняється об'єкт після дій з ним, а також швидка пристосовуваність дій об'єкта до нової ситуації. В структуру гри входять: ролі, що взято на себе гравцями, ігрові дії як засіб реалізації цих ролей, ігрове вживання предметів, тобто заміщення реальних предметів ігровими, реальні стосунки між гравцями. Одиницею гри, та в той же час центральним моментом, що об'єднує всі їі аспекти, $є$ роль. Стосовно саме рольового статусу учасників цього процесу слід зазначити, що, попри розуміння ними тимчасовості, «несерйозності» гри, від них вимагається випромінювання дійсних, не штучних емоцій, 
справжньої рефлексії, емпатії тощо. Гра не відбудеться, «розсиплеться» «розтане», якщо гравець не перейметься своєю роллю і не відчуватиме напруження, азарту, зосередженості, страху, радості, або інших емоцій згідно визначеного правилами рольового статусу. Сюжетом гри постає відтворена в ній царина дійсності. В грі відбувається формування довільної поведінки особистості, її соціалізація. Характерною особливістю гри $€$ її двоплановість, що притаманна драматичному мистецтву.

В межах педагогічних досліджень гра експлікується як метод передачі знань, підготовки до майбутніх життєвих ситуацій, морально-естетичного розвитку особистості. Здавна та традиційно гра вважалась принципово непродуктивною діяльністю, проте, наголошуючи на цій її особливості, і Платон, і Аристотель, а також стоїки та мислителі Відродження вбачали в грі певним чином діючий, впливовий, дієвий засіб виховання. Тому спочатку нарисово, потім дедалі чіткіше, думка дослідників корегується на поновленому розгляданні функції гри в навчальному процесі: гра, на їх думку, дозволяє ставити суб'ект навчання в активну позицію, чим вивільняє його творчо-пізнавальний потенціал; завдяки наявності іманентно притаманній їй складовій - правилам - сприяє розвитку здібностей суб'єкта, що грає, до саморегуляції, самоорганізації, самоконтролю, власної діяльності.

Гра надає процесу навчання статусу суб'єкт-об'єктних відносин, у процесі яких нивілюються початково різнорівневі стосунки «учитель-учень», «дорослий-дитина», «викладач-студент» завдяки наявності ігрової атмосфери - творчої рольової взаємодії, що має на меті партнерське вирішення навчально-пізнавальних проблем. Зусиллями багатьох дослідників було створено різноманітні педагогічні концепції гри, що надалі було розвинено та розширено з урахуванням сучасної ситуації. Одну з перших спроб педагогічного осмислення досвіду ігрового навчання здійснили автори теорії проблемно-модельного навчання М.Ж. Арстанов, П.І. Підкасистий, Ж.С. Хайдаров. На основі сполучення історичного та логічного підходів вони розглядають окремі види ігор, пропанують класифікацію та «дерево» ігор.

Переваги навчальних занять в формі дидактичної та ділової гри переконливо показано в навчальному посібнику, створеному групою авторів Криворізького державного педагогічного університету [8]. В ході дослідження основних понять та категорій, які позначають феномен гри, автори підкреслюють ті характеристики імітаційно-ігрового навчання, що забезпечують надання навчально-пізнавальній діяльності студентів імпульс творчості, створення умов для самореалізації особистості.

Естетика тлумачить гру як найдавнішу форму естетичної діяльності, тобто неутилітарної, здійснюваної заради неї самої, та такої, що надає її учасникам почуття естетичної насолоди, задоволення, радості. Слід за- 
значити, що негативний сенс гри, про який так непрозоро зазначалося в межах розвитку романтичної свідомості, та якому надавався статус метафори життя (гра як нещирість, блюзнірство, омана або демонстрація надособистісних, інфернальних сил, що грають людиною, згодом втрачають свої позиції), відкриває, скоріш за все, зміст екзистенцій, акцентує настанову на розуміння гри як «форми вільного самовиявлення людини, що має на увазі реальну відкритість світові можливого і розгортається або у вигляді змагання, або у вигляді вистави (виконання, репрезентації) будь-яких ситуацій, змістів, станів» [7, с. 182].

Як зазначалося вище, дійсний початок фундаментальним педагогічним розробкам теорії ігор було покладено в роботі Ф.Шіллера «Листи про естетичне виховання». В цій роботі він розвиває кантівське протиставлення теоретичного і практичного, матерії та форми. Саме в естетичному він вбачає середину між означеними протилежностями, проте, не залишає без уваги той факт, що людське буття позначено двома також протилежно спрямованими векторами: чуттєвим потягом - до матерії, та потягом до форми. Підсумком схрещення цих векторів, на погляд Шіллеpa, є потяг до гри, або інстинкт гри, що спонукає сприймати свій предмет так, начебто він сам виробив його, та виробляти так, як прагне сприймати почуття. Потяг до гри, поєднуючи два інших потяги, силує Людину і морально, і фізично; проте, тим самим і звільнює їі. Якщо предметом чуттєвих потягів $є$ життя в самому широкому розумінні, а предметом потягу до форми - образ, форма, то предмет потягу до гри є живий образ, тобто краса. Гра, таким чином, постає майже центральним поняттям як засіб вільного, самодіяльного розкриття всіх сил людини. Людина творить під час гри реальність вищого порядку - «естетичну реальність» та творить саму себе як всебічно розвинену гармонійну особистість, сподіваючись відновити внутрішню цілісність особистості [11].

До взаємодії гри та культури звертається іспанський філософ Хосе Ортега-і-Гассет [10], який вбачає порятунок сучасної культури саме в грі, що дає можливість відходу від «будь-якої патетики» від «переобтяженості людяністю». Тому він вітає новий стиль в мистецтві, сповнений святковістю спортивних ігор, емоціями і запалом, що втілюють юний дух і динаміку сучасної епохи.

Сучасні ігрові концепції збагачують новими значеннями поняття гри. Воно охоплює зовні несхожі явища - від радісного дитячого змагання «в класики» до реалізації трагічної фабули на театральній сцені; від численних форм розваг і відпочинку до абсолютизації ірраціонального начала («гра долі», «гра випадку»); від описової характеристики певного руху («гра світла», «гра фарб») до виявлення глибинних основ буття (гра як універсалія). Саме подібна множинність тлумачень і по сьогодні приваблює науковців до вивчення сутності гри, її генези, структури, функції в 
житті людини і культури.

\section{1 Бібліографія}

[1] Apистотель. Сочинения в 4-х томах. Т. 4.- М.: Мысль, 1983.

[2] Берн Э. Игры, в которые играют люди. Люди, которые играют в игры. - СПб.: Лениздат, 1992.

[3] Бычков В.В., Бычков О.В. Игра // Новая Философская энциклопедия. - М.: $2001-$ T. 2. - С. 67-70.

[4] Выготский Л.С. Роль игры в психическом развитии ребенка // Вопросы психологии. - 1966. - №6. - С. 62-76.

[5] Выготский Л.С. Вопросы детской психологии. Собр.соч. в 6 т., М.: Педагогика, 19. - Т.6.

[6] Грязнов А.Ф. Эволюция философских взглядов Витгенштейна.- М.: Изд-во МГУ, 1985.

[7] Канарский A.C. Диалектика эстетического процесса. Генезис чувственной культуры. - К.: Вища школа,1982.

[8] Кондрашова Л.В., Виевская М.Г., Савченко Л.А. Имитационно-игровое обучение в высшей школе. Учебное пособие. - Кривой Рог, 2001.

[9] Философский энциклопедический словарь.-2-е изд. / Редкол. С.С. Аверинцев и др. - М.: Сов. энциклопедия, 1989.

[10] Хосе Opmeга-и-Гассет. «Дегуманизация искусства» и другие работы. Эссе о литературе и искусстве: Пер. с исп. - М.: Радуга, 1991.

[11] Чулошникова M.A. Игра как проявление реальности сознания и специфика субъектно-объектных отношений // Зб. наукових праць другої міжнародної науково"Опрактичної конференції «Інформенергетика II-го тисячоліття: соціолого-синергетичний та медико-екологічний підходи». - Випуск II. - Київ-Кривий Ріг, 2003.

[12] Чулошникова М.А. Игровая сущность субъектно-объектных отношений // Актуальні проблеми духовності. - Вип. 5. - Кривий Ріг, 2004.

[13] ШШилер Ф. Письма об эстетическом воспитании. Собр. соч., т. 6. M., 1957.

[14] Эльконин Д.Б. Психология игры. - М.: Педагогика, 1978. 